Canadian Journal of Regional Science

Revue canadienne des sciences régionales

\title{
Introduction. Special Issue in Honour of Mario Polèse
}

\section{Donald J. Savoie}

Volume 42, numéro 1, 2019

En l'honneur de la carrière de Mario Polèse

Soumis : 23 septembre 2019

Accepté : 2 octobre 2019

URI : https://id.erudit.org/iderudit/1083634ar

DOI : https://doi.org/10.7202/1083634ar

Aller au sommaire du numéro

Éditeur(s)

Canadian Regional Science Association / Association canadienne des sciences régionales

ISSN

0705-4580 (imprimé)

1925-2218 (numérique)

Découvrir la revue

Citer ce document

Savoie, D. J. (2019). Introduction. Special Issue in Honour of Mario Polèse. Canadian Journal of Regional Science / Revue canadienne des sciences régionales, 42(1), 3-3. https://doi.org/10.7202/1083634ar d'utilisation que vous pouvez consulter en ligne. 


\title{
CANADIAN JOURNAL \\ OF REGIONAL SCIENCE \\ REVUE CANADIENNE DES \\ SCIENCES RÉGIONALES
}

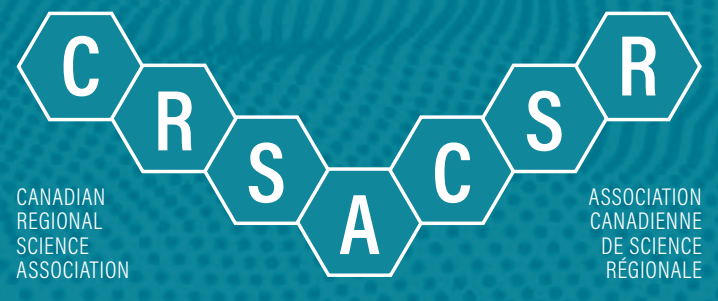

\section{INTRODUCTION}

\section{SPECIAL ISSUE IN HONOUR OF MARIO POLĖSE}

\section{Donald J. Savoie}

\author{
Donald J. Savoie \\ Professeur et titulaire de la Chaire de recherche du Canada en administration publique et gouvernance \\ Université de Moncton \\ Pavillon Léopold-Taillon, pièce 410 \\ 18, avenue Antonine-Maillet \\ Université de Moncton \\ Moncton, N.-B. E1A 3E9 \\ donald.savoie@umoncton.ca \\ Soumis: 23 septembre 2019 \\ Accepté: 2 octobre 2019
}

All students of regional economic development, regional economics and regionalism familiar with the literature know Mario Polèse's work. I have often turned to his contributions on numerous occasions in my own work.

Mario Polèse has this rare ability to delve into the details of an issue, a concept or a question that requires a highly quantitative analysis and just as easily step back to look at the broad public policy environment. He has the remarkable ability to make insightful contributions to both. I have read Polèse's take on the growth pole concept which I found extremely valuable. The next time I consulted his work, I was reading his take on the forces that shape a firm's decision to locate in a given community. This speaks to Polèse's ability to move with ease from macro issues down to the level of a firm making a decision.

There is yet another quality to Mario Polèse's work that stands out among many of his peers. He makes his work accessible, not only to the specialists, but also to practitioners and students starting to take an interest in regional and urban economics. I recall reading Polèse on community economic development. He skilfully combined a highly technical analysis with images that brought his material to life for beginners in the field. In his take on smaller, remote communities struggling to remain viable, he put his finger on the important issue with an image - who, he asked, would be the last to leave to turn off the lights?
The collection of essays in this special issue of the Canadian Journal of Regional Science is a fitting tribute to a giant in the field. The collection deals with issues that Mario Polèse has addressed throughout his career. I applaud the choice of both authors and papers. They represent well Mario Polèse's approach to the field. Richard Shearmur takes a comprehensive look at Polèse's contributions, underlining his integrity and fearlessness. Chloé Duvivier, meanwhile, provides a quantitative literature review on a timely issue for students of regional economic and public policy - broadband and firm location.

The above brings me to make one more observation about Mario Polèse's contributions, one that needs to be underlined. Polèse's work and influence extends beyond the halls of academe. I know that a number of government officials at both the provincial and federal government levels have often consulted his work in their efforts to shape public policy and to offer advice to policy makers.

I conclude with one wish - my hope is that now that Mario Polèse is Professor Emeritus, he will continue to contribute to the regional and urban development field. His The Wealth and Poverty of Regions: Why Cities Matter has joined the ranks of the classics in the field. This contribution alone gives Polèse the standing to share his wisdom and become a mentor to the next generation of students in regional economic and urban studies. 